\title{
FORMATION OF SOCIAL AND LEGAL COMPETENCIES OF FUTURE SOCIAL WORKERS IN THE PROCESS OF PREPARATION TO WORK WITH YOUNG FAMILIES
}

\author{
HALYNA MYKHAILYSHYN, MIROSLAVA DOVHA
}

\begin{abstract}
The problem of professional training of future social workers in the context of formation of necessary knowledge, skills and abilities is actualized in the article. The views of scientists on the content of the notions of competency, competences and professional competency of social workers are considered. The author's definitions of "competency", "competences", "professional competency" and "social and legal competency" are also suggested. Professional competency is the formation of various components, a system of certain components and personality and psychological properties of the individual, which includes knowledge, skills, abilities, personal characteristics and organizational and pedagogical conditions for training future specialists. The main components of socio-legal competencies are identified: cognitive, activity-operative, motivational, personal and instrumental. It also identifies the types of social and legal knowledge that future social workers will receive in the course of their professional training and the skills and abilities of their professional activity. Knowledge of social and legal activity for work with young families was divided into types by the following criteria: socio-legal knowledge in the fields of law, socio-legal knowledge obtained by the degree of their hierarchy in legislation, socio-legal knowledge of the degree of formation, social and legal knowledge on the degree of use of the acquired information. In addition, the acquired knowledge and skills of social and legal activity, which is an activity-operational component of social and legal competency, are accordingly formed in relation to the acquired social and legal knowledge: individual organizational skills, skills and abilities in forecasting and design work, skills and counseling skills.

An instrumental component of the formation of complex knowledge of social and legal activity is suggested where social design as a modern progressive tool for overcoming social problems in dealing with young families was highlighted. A social project called "Education for a Young Family" was developed. It is proved that without all the components, social and legal activity will not be fully implemented and social and legal competency will be impossible to develop.
\end{abstract}

Keywords: competency, competences, professional competency, social and legal competency, components of social and legal competency, social and legal knowledge.

\section{INTRODUCTION}

Vocational training of future social workers in modern social conditions should be carried out at the proper level, so that the educational process of higher educational institutions should be carried out with the help of new methods, forms, means of education for the formation of complex knowledge, which could then be applied in practical activity to future specialists in the social sphere. But it is 
necessary that such professional training ensures a harmonious development of the student's personality as a future social worker, satisfies educational and spiritual needs in the process of educational activity. Vocational training is one of the important means of professional development of a social worker.

In recent years, a number of scholars have explored the issues of vocational training for future social workers in their practice. Among them, O. Budnyk, T. Golubenko, I. Zimnia, A. Kapska, O. Karpenko, O. Plakhotnik, V. Polishchuk, A. Popova, L. Tuptia, O. Yankovich, T. Yarkina, and others. But in the writings of these and other authors, the contents of the professional training of future social workers to work with young families, including the content of complex knowledge of social and legal activities, is not fully covered.

Preparing future social workers for professional activities within the study is viewed from the perspective of a competency-based approach that shifts the emphasis from the process of accumulation of knowledge, skills and abilities to the plane of formation and development of students' ability to practice, apply the acquired knowledge and experience in professional activity. Therefore, the main characteristics of a social worker as a subject of professional activity are not only knowledge, skills and abilities, but also motivation to master the profession; practical, humanistic and professional orientation; professional-value orientations; personal potential; professionally determined (significant) qualities; professional culture; individual style of behavior; professional competence and the need to achieve professionalism [19, p. 8].

The notion of competency, professional competency and its components has interested many national and foreign scientists. In particular, theoretical analysis of competencies and competences (N.Briukhanova, M.Golovan, N.Gorishna, V.Kraevskiy, A.Hutorskiy, etc.), theoretical analysis of professional competencies and professional competencies of specialists in the social sphere, structure and its components (O.Andrus, S.Batyshev, L.Vashchenko, I.Zimnaia, O.Ignatieva, O.Derkach, V.Dudariov, V.Domin, S.Kalashnikov, A.Kapska, A.Markova, I.Mishchenko, F.Mukhametzanov, I. Podlasy, O.Pometun, V.Savitska, G. Skachkova, N.Povyakel, S.Harchenko, E.Tsarkova, etc.).

The purpose of the article is to determine the structure of social and legal competencies of a social worker in dealing with young families.

\section{ANALYSIS AND DisCUSSION}

Competency is closely linked to competence, but these are different concepts. Differentiating between the terms "competency" and "competence", V.V. Kraevsky and A.V. Khutorskiy explain that competence means a range of issues in which a person is aware and has experience, and capacity is a combination of relevant knowledge and abilities in a particular field of activity that allow to act effectively in it [22, p. 56].

Under the competency N. Briukhanova understands the property of a professional, which indicates his ability to act expediently and effectively in certain circumstances, that is, to realize certain groups of experience in certain areas or stages of activity, in particular professional activity [5].

In N. Horishna's opinion, the term "competence" refers to a range of issues on which a person has the knowledge and experience, or the authority of a particular institution or person. The competence of the specialist is determined by the normative documents of the organization and is reflected in job descriptions. Capacity is an indicator of the formation of appropriate skills and the degree of their possession. Thus, the basis of professional competencies is formation of knowledge, abilities and professional skills [8, p. 115].

M. Golovan states that a competence can be understood as a certain norm, which indicates the possibility of solving professional problems, and under the capacity- the level of competences development or the ability to assess the achievement of the norm [9].

Therefore, with regard to the concept of competencies, we agree with the view of scholars that competency and competence are not identical concepts, but are closely related. That is why we are offered to define competences as a norm, a standard that is enshrined in the legislation on the 
educational training of a certain category of persons. With regard to the concept of competencies, it is the level of knowledge and abilities, skills and competencies acquired in the course of professional activity, which is identified by the norms of competences. Therefore, capacity is a broader concept because it includes a set of professional competences.

The term "professional "competency" in the "Encyclopedia of Education" is defined as "an integrative characteristic of the professional and personal qualities of a specialist, reflecting the level of knowledge, skills, experience sufficient to achieve the goal of a particular activity, as well as the moral position of the specialist" [10].

The professional competency of social workers is defined as a qualitative characteristic of the subject of activity, which reflects the integral nature of his training and the readiness of the individual to carry out this activity [23, p. 56].

According to O. Derkach, professional competency is the only complex of knowledge, skills, psychological features (qualities), professional positions and axiological variants [1].

In the context of N. Povyakel's research, professional competency is seen as an integral characteristic of professionalism, which allows to determine the level of preparedness and ability of a person to successfully complete professional tasks and perform professional duties. Therefore, professional competency acts as a major component of professionalism and a determining factor in the success of the implementation of social and vital functions of specialist [18].

Based on the above, we offer the definition of professional competencies as a set formed at the theoretical and practical level of knowledge, skills, personal and psychological qualities acquired in the process of professional and subject activity.

Undoubtedly, professional competency is the formation of various components, a system of certain components and personality and psychological properties of the individual, which includes knowledge, skills, abilities, personal characteristics and organizational and pedagogical conditions for training future specialists.

I. Pidlasiy determines the knowledge required for professional activity and the ability to put that knowledge into practice by a component of professional competencies; I. Mishchenko emphasizes the presence of special education, general and special erudition, constant improvement of professional training; A. Kapska refers to the components of the possession of theoretical knowledge and skills to use adequate technologies and to perform appropriate social roles in professional activity, etc. However, these components can be supplemented with other equally important components [14].

Describing a social worker as a holistic subject of a professional activity, researcher O. Karpenko, following the positions of different schools of social work, identified the following groups of professional and pedagogical knowledge that a specialist should possess: methodological knowledge, theoretical knowledge, methodological knowledge and technological knowledge [11, p. 93].

Famous researcher of professional competencies V.A. Demin points out that skill is the main component of professional competences. Analyzing different approaches to the study of skills, it brings the essence of professional competencies to the level of personality skills, which reflects the degree of conformity of particular competences and allows us to act constructively in changing social conditions [16].

According to N. Horishna, the basis of professional skills of a social worker is based on an organized system of knowledge, but the stock of theoretical knowledge does not yet ensure success in social work. Appropriate skills are required for the effective implementation of social work [8, p. 116].

Therefore, the criteria of professional competencies of the future specialist are the formation of professional knowledge, skills, personal qualities that are necessary for his professional activity. Their acquisition is carried out gradually, based on the components of successful professional activity of a future specialist - professional selection, level of training, personal qualities of a young person, his motives, aspirations, level of aspirations, primary in the process of professional training of a specialist in accordance with the requirements of society (industry education standards), experience, qualifications, working conditions [2, p. 287]. 
The social worker, in particular, should be able to: purposefully and intelligently listen to others; collect information to prepare social history, evaluation, report; to form and maintain professional relations aimed at providing social assistance; to observe and interpret verbal and non-verbal behavior, using knowledge of personality theory and diagnostic methods; to direct customer efforts to solve their problems and win their trust; discuss sensitive issues with the necessary amount of attention and support, instilling in the client confidence; creatively solve client's problems; determine the moment of suspension of therapeutic assistance to the client; conduct research and interpret their results; to mediate and negotiate between the conflicting parties; to provide communication

The structure of professional competencies of a social worker consists of certain types of competences: functional (professional and special pedagogical knowledge and skills, methods of activity), normative-legal (knowledge of the basic provisions of state normative-legal acts governing the functioning of the social sphere in Ukraine), social (responsibility for the results of their work, the desire for sovereignty), communicative (the ability to coordinate their actions, to choose the optimum style of communication without instructive actions in different situations) [3, p. 23].

The components of professional competencies are identified by Karpenko, in particular the functional, personal and subject aspect of activity [13, p. 33].

The structure of professional competencies of a specialist in the social sphere is considered in the works of F. Mukhametzianova:

- social and legal competency - knowledge and skills in the sphere of interaction with public institutions and people, as well as possession of techniques of professional communication and behavior;

- special competency - the willingness to perform specific activities independently, the ability to solve typical professional tasks and evaluate the results of their work, the ability to independently acquire new knowledge and skills in a specialty;

- personal competency - the ability to continuous professional growth and professional development, as well as the realization of oneself in professional activity;

- auto-competency - adequate understanding of their socio-professional characteristics and ownership of technologies to overcome professional destruction;

- extreme competency - the ability to act in extreme situations [17].

As a result of performing relevant professional tasks and responsibilities, social workers carry out various activities that practically correspond to the types of their competences. Because, we live in a rule of law, where legal knowledge is now a necessity, given today's living conditions and social and legal protection by the state. Therefore, we would like to characterize the social and legal activities of social workers and to show the formation of complex knowledge in a social worker with a young family.

Socio-legal competency of a social worker is a set of qualities that reflect the degree of qualification, the level of legal knowledge, skills, readiness and ability associated with the implementation of social and legal activities [20].

Depending on the nature of the professional activity of the social worker by appointment, at the place of work, the content of social and legal competences becomes a special content. Socio-legal competency, like any other, includes the following structural components:

- motivational - includes the motives, goals, values of the specialist, involves the attitude to professional activity as a value, the need to develop their social and legal competencies; striving for personal self-improvement. Functional purpose of the motivational-value component is that its formation mediates the development of other components of social and legal competencies;

- cognitive - knowledge of theoretical and methodological bases of jurisprudence; regulatory legal acts; technologies of social and legal work; modern information technologies; requirements for a modern social worker;

- activity-behavioral - determines the style of behavior, the choice of ways of behavior and the solution of practical problems, includes the conditions for successful realization of social and legal competencies. This component implies the availability of a specialist's readiness for self-realization in 
social and legal activities, concrete results achieved in the process of its implementation, basic qualities inherent in the behavioral level, development of the ability to solve social and legal problems when interacting with the client;

- value-semantic - a set of psychological characteristics of a person (professionally significant qualities of a specialist and his values), readiness for the manifestation of personal initiative; value attitude to the profession; willingness to work with those who need help; value attitude to events, to people, to oneself;

- emotional-volitional - involves emotional-volitional self-regulation of personality behavior in the situation of professional activity in order to achieve high results. The manifestation of emotionalvolitional activity includes emotionality as a positive emotional factor - a reaction to success and failure - and emotionality - a value indicator of the subject's awareness of the need for social and legal activity, a positive active emotionally colored attitude to personal and professional self-improvement;

- reflexive - is the tracking of the goals, process and results of one's activity, as well as the selfassessment of the specialist on the basis of self-awareness and reflection, awareness and appreciation of those internal changes that occur in him, as a changing personality, subject of activity and relationships. Only adequate self-assessment ensures success in the development of socio-legal competencies. Reflection of a person as a subject of social and legal competencies covers all its components: understanding of one's level of professional competencies, style of behavior, peculiarities of valuemotivational sphere and other issues. Consider some of these components in more detail [20].

A social worker performing social and legal activities must have the appropriate level of knowledge to defense and protect the legal rights and interests of different segments of the population, in our case young families. This should be knowledge of various fields of law, assistance in obtaining various benefits, social benefits, proper registration of documents, etc. Therefore, we have developed a structure for the formation of social and legal competencies of future social workers in the process of preparation for work with young families (Figure 1)

A structure for the formation of social and legal competence of future social workers in the process of preparation for work with young families (Figure 1)

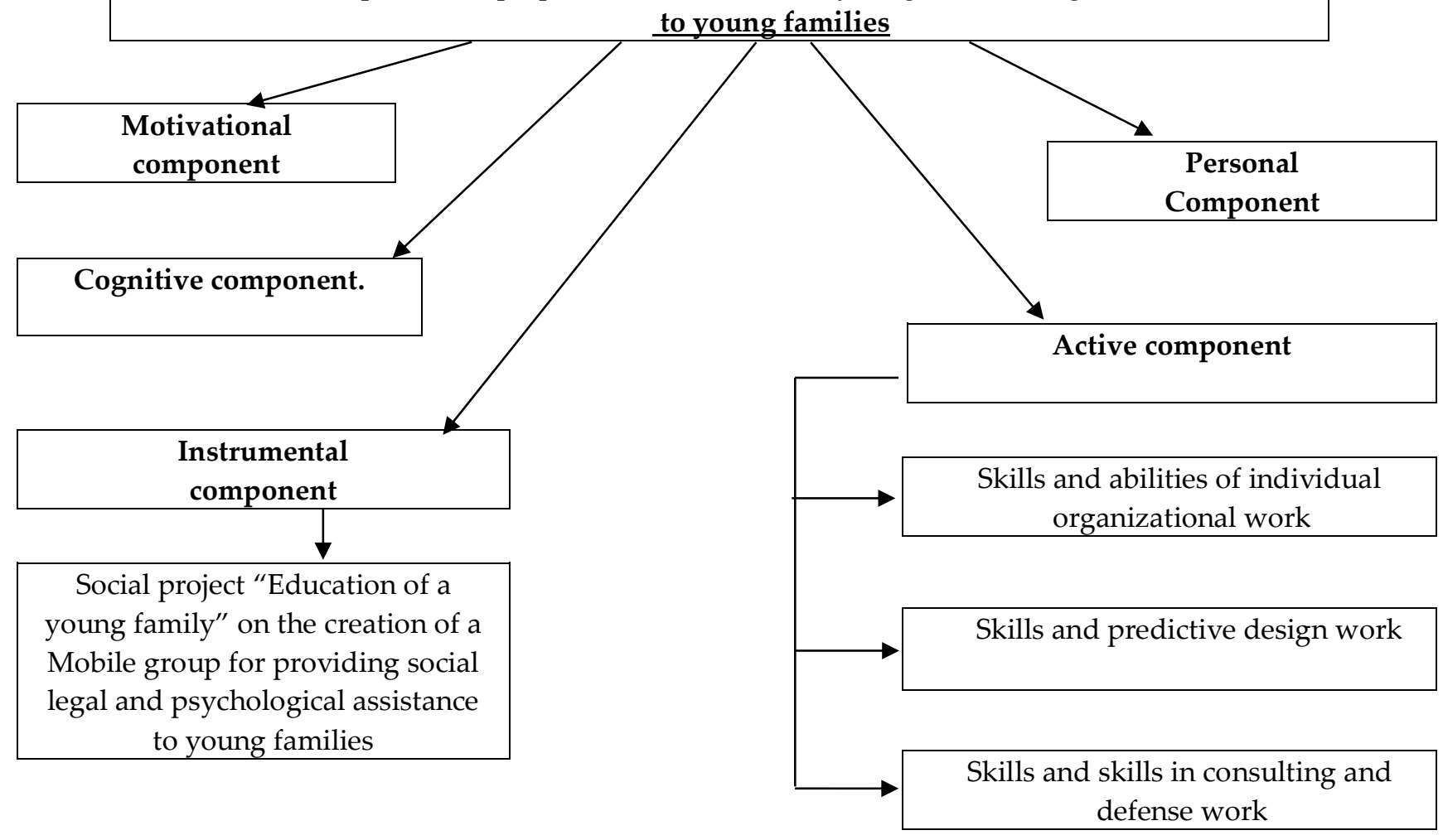

Fig 1. A structure for the formation of social and legal competence of future social workers in the process of preparation for work with young families. 
Cognitive component. We divided the knowledge of social and legal activity for work with young families into types by the following criteria:

1) Socio-legal knowledge in the fields of law:

a) knowledge acquired in the field of family law (Family Code of Ukraine - Section II. Rights and obligations of spouses, Section III - Rights and duties of mother, father and child, etc.);

b) knowledge acquired in the field of civil law (Civil Code of Ukraine - Article 1178 Compensation for damage caused by a minor, etc.);

c) knowledge acquired in the field of labor law (Code of Labor Laws of Ukraine - Part 1 Article 179 on maternity leave, etc.);

d) knowledge acquired in the field of administrative law (Code of Ukraine on Administrative Offenses - Article 184 Failure of Parents or Substitutes to Observe Obligations for the Education of Children, etc.);

e) knowledge acquired in the field of criminal law (Criminal Code of Ukraine - Art. 166 malicious failure to fulfill the duties of caring for a child or a person in charge of custody or custody, etc.);

f) knowledge acquired from other fields of law (business, land, etc.)

2) Socio-legal knowledge obtained by the degree of their hierarchy in legislation:

a) knowledge obtained from international law (Universal Declaration of Human Rights, European Convention on Human Rights, Declaration of the Rights of the Child, UN Convention on the Rights of the Child, etc.);

b) knowledge is obtained from legislative acts of national law (Constitution of Ukraine, Family Code of Ukraine, Civil Code of Ukraine, Code of Laws on Labor in Ukraine, Laws of Ukraine "On State Aid to Families with Children," On Compulsory State Pension Insurance, etc.);

c) the knowledge was obtained from the by-laws (decrees and orders of the President of Ukraine, the resolution of the Verkhovna Rada of Ukraine and the Cabinet of Ministers of Ukraine - the resolution of the Cabinet of Ministers of Ukraine "On measures to strengthen maternity and childhood protection", etc.);

d) knowledge is obtained from internal local normative acts (normative acts (orders, decision provisions, orders) that are adopted by the employer at the enterprise and comply with the higher legislation and usually refer to internal labor regulations, remuneration, etc.).

3) Socio-legal knowledge of the degree of formation:

a) educational knowledge (formed in the process of studying the disciplines of the legal nature in the pedagogical establishments of higher education. For example, law, social security law, law in social work, the legal foundations of social work, etc.);

b) practical knowledge (formed in the course of practical legal activity);

c) educational and practical (formed in the process of mastering the theoretical knowledge acquired during training and consolidation of this knowledge in practical activity)

4) Social and legal knowledge on the degree of use of the acquired information:

a) theoretical (knowledge of various fields of law);

b) theoretical and practical (application of the acquired knowledge from different branches in the process of social and legal activity, ability to use various technologies to help young families);

Therefore, based on the above classification of knowledge of social and legal activities in dealing with young families, a social worker should know what constitutes a cognitive component of sociolegal competencies:

1) norms of normative legal acts and extension of the laws;

2) legal terms that are necessary for a social worker to work with young families;

3) family provisions (in our case young family);

4) different types of social assistance for young families;

5) terms of funding, sources of funding, social assistance organizations, and programs to help young families. 
Active component. In addition, the acquired knowledge and skills of social and legal activity, which is an activity-operational component of social and legal competencies, are accordingly formed in relation to the acquired social and legal knowledge:

- Individual organizational skills (use and select the main provisions of legal documents, be able to analyze them in a specific case of social and legal activities; inform young families about their rights to social security, services and responsibilities; organize and assist in the field of social and legal activities for young families);

- skills and abilities in forecasting and design work (to plan and forecast interactions with clients and organizations, the consequences of such interaction, to evaluate their actions to help young families in solving their professional responsibilities;

- skills and counseling skills (assistance to young families; cooperation between families, parents, the public and their legal education; to protect the rights of young families in different instances; to assist in the writing of various documents of social and legal nature).

Motivational component. In addition to the acquired theoretical and practical knowledge, skills and motivations, there must be motivation for acquiring appropriate social and legal competencies (motivational component of social and legal competencies) and personal characteristics of the future social worker (personal component).

The motivational component as a necessary element of successful professionalization of a specialist in social work is given by O.I. Poplar, noting that it determines professional suitability for practical work [21].

Purposeful work on the formation of motivational-value learning, according to T.A. Golubenko, should be the main component of the learning process because it ensures the conscious nature of setting personal goals and regulating students' own educational and cognitive activity [7].

The motivational factor involves the transformation of knowledge, skills and abilities into the means of personal and professional growth, thereby sending the quality of student activity and the quality of social worker as a professional [12]. Therefore, it is a testament to the independence, creativity and initiative of the future specialist in the field of social and pedagogical activity [24].

Personal Component. Scientists identify the following groups of personal qualities of a social worker:

1. Psycho-physiological characteristics, which depend on the ability to this activity (mental processes (perception, memory, imagination, thinking), mental states (fatigue, apathy, stress, anxiety, depression), attention as a state of consciousness, emotional and volitional manifestations (restraint, indifference, persistence, consistency, impulsivity).

2. Psychological qualities that characterize a social worker as a person (self-control, self-criticism, self-esteem of one's own actions, stressfulness (physical training, self-suggestion, ability to switch and manage one's own emotions).

3. Psychological and pedagogical qualities on which the effect of personal attractiveness depends. (sociability (ability to quickly establish contact with people); empathy (capturing people's moods, revealing their attitudes and expectations, empathy); attractiveness (external attractiveness of the individual); eloquence (ability to speak skillfully, speaker protection] [6, p. 132].

Social worker as a specialist in the social sphere, who can work at different levels of implementation of social policy of the state - at the level of management, logistical and legal support, education, health care and directly practice social work. In addition, the social worker must be a participant in the joint activity, the organizer of this activity, he is a kind of spiritual mentor, who leads a person for a long time, provides support, takes care of the formation of social values in society. At the same time, he and the social therapist, preventing and resolving conflict situations. This allows one to speak of a specialist in the social sphere as a holistic subject of professional activity [4, p.25]

Tool Component. To this component we include modern information resources and technologies, communication technologies and products, etc., which are used in social work by social workers in work with young families. 
Important in the professional training of future social workers to work with young families in the future professional activity is played by the stagnation of modern progressive tools, which in our study is social design, which is in the stage of formation and development. We have developed a social project called "Education for a Young Family". The aim of the project is to increase the level of social and legal literacy of young families and social and legal protection through the creation of a modern Mobile Group on providing free social, legal and psychological assistance to young families at the level of ATS. The activities of the Mobile Group should be aimed at analyzing, forecasting and providing legal assistance by educating, informing and advising on the rights, responsibilities and responsibilities of family members in various activities, getting acquainted with benefits, legislative and regulatory documents, etc.

On the basis of the social and legal activity of social workers with young families they consider, we are offered to determine the social and legal competencies of a social worker as a set of the acquired knowledge, skills and abilities at the acquired theoretical and practical level of professional training while working in the field of social and legal protection the available motivational component and personal qualities of the social worker.

\section{CONCLUSIONS}

Thus, within the framework of the study of this topic, we have identified five components of the formation of complex knowledge of social and legal activity of future social workers to work with young families, which are: cognitive, activity-operative, motivational, personal and instrumental components of social-legal the competencies of social workers to work with young families. Because without all the components, social and legal activity will not be fully implemented and develop social and legal competence. Certainly, all the components are interconnected and develop together, which testifies to constant personal self-development and self-improvement of social workers.

Therefore, successful work with clients (in our case young families) requires the proper professional training of future social workers to work with them and the ability to apply new social tools in their future professional work, since social transformations are the cause of various problems of target groups, that need to be addressed immediately.

\section{REFERENCES}

[1] Derkach A.A. (Ed.) Acmeology. RAGS Publishing House, Moscow, 2002. (in Russian)

[2] Andrus O. Modern Aspects of Students' Professional Training in Technical Universities. Problems of modern teacher preparation, 4 (2) (2011), 283-294. (in Ukrainian)

[3] Andrushchenko V.P. Social work: management of social work. Book 7. DCSSM, Kyiv, 2003. (in Ukrainian)

[4] Bibik D.D. Topical problems of training specialists in the social sphere: abstracts of reports of the International scientific and practical conference. Khmelnytskyi HIST of the University of Ukraine, 2012. (in Ukrainian)

[5] Bryukhanova N. Approaches to Understanding Competencies and Competences in Education. Pedagogy and psychology of vocational education, 4 (2007), 40-49. (in Ukrainian)

[6] Semigina T.V. (Ed.) Introduction to Social Work: A Tutorial. Academvid, Kyiv, 2005. (in Ukrainian)

[7] Golubenko T.O. Features of the process of forming the readiness of future social workers for patronage work with elderly people. (in Ukrainian)

[8] Gorishna N. Professional competency of a social worker as a component of his professional training. Uzhgorod University Scientific Bulletin: The series "Pedagogy. Social work", 16-17 (2009), 144-117. Available at: http: //www.nbuv.gov.ua/portal/natural/Nvuu/Ped/2009/www17/Horishna.pdf. (in Ukrainian)

[9] Zvereva I.D. (Ed.) Encyclopedia for social professionals. Universe, Kiev, Simferopol, 2013. (in Ukrainian) 
[10] Kapska A.Y. Technologies of social and pedagogical work with families. Slovo Publishing House, Kyiv, 2015. (in Ukrainian)

[11] Karpenko O.G. Introduction to the specialty "Social work". Slovo, Kyiv, 2011. (in Ukrainian)

[12] Karpenko O.G. Motivation in the structure of social worker activity. Journal of Ivan Franko Zhytomyr State University, 17 (2014), 36-39. Available at: http://eprints.zu.edu.ua/id/eprint/960. (in Ukrainian)

[13] Karpenko O.G. Formation of professional competencies of a social worker as one of the conditions for successful practical activity. Scientific journal of M.P. Dragomanov NPU. Sociology Social work social pedagogy. Management, 11 (2007), 32-39. (in Ukrainian)

[14] Kapska A.I., Volynska L.V., Karpenko O.G., Filippchuk V.S. Communicative professional competency as a condition of social worker interaction with the client: teaching method. manual. The state. the center of soc. Youth Services, M.P. Drahomanov NPU, Kyiv, 2003. (in Ukrainian)

[15] Kornyushina R.V. Foreign experience of social work. Far Eastern University Publishing House, Vladivostok 2004. (in Russian)

[16] Larner I., Griz Y., Teper J. Development and professional understanding of social work in German women. Social work on the eve of 2000: ways and goals of professional formation. Institute of Social Work, Moscow, Berlin, 1998, 18-25. (in Russian)

[17] Mukhametzianova F.Sh. Theory and practice of remote training of a social sphere specialist in the region. Kazan Science, 2002. (in Russian)

[18] Povyakel N.I. Professional psychogenesis of self-regulation thinking of a practical psychologist: Monograph. NPU them. M.P. Drahomanov, Kyiv, 2003. (in Ukrainian)

[19] Savitska V.V. Preparation of future social workers for professional activity on the basis of proxological approach: author. diss. for the sciences. degree of Cand. ped. Sciences: Special. 13.00.04. Exactly, 2015, 20 p. (in Ukrainian)

[20] Socio-pedagogical activity. Short course of lectures on the discipline "Legal support of social work". Available at: https://studme.com.ua/13560615/sotsiologiya/sotsialno-pravovaya_kompetentnost_sotsialnyh _rabotnikov_kak_osnovnoy_element_professionalnoy.htm (in Ukrainian)

[21] Popol O.I. Health-saving competency as a component of social worker professionalism. Available at: http://dspace.tnpu.edu.ua/bitstream/123456789/484/1/Topol.pdf (in Ukrainian)

[22] Khutorskiy A.V. Key competences as a component of personality-oriented education. Public education, 2 (2003), 55-61. (in Russian)

[23] Yarkina T.F. Social pedagogy and social work in the context of international cooperation. ACOPiR, Moscow, 1998. (in Russian)

[24] Mykhailyshyn H., Budnyk O. Social and Educational Support of Young Parents and their Children. Journal of Vasyl Stefanyk Precarpathian National University, 5 (1) (2018), 107-113. doi: 10.15330/jpnu.5.1.107113

Address: Halyna Mykhailyshyn, Miroslava Dovha, Vasyl Stefanyk Precarpathian National University, 57 Shevchenko St., Ivano-Frankivsk 76018, Ukraine.

E-mail: mirosya29@meta.ua; halyna.mykhailyshyn@pnu.edu.ua.

Received: 02.03.2021; revised: 10.03.2021.

Михайлишин Галина, Довга Мирослава. Формування соціально-правової компетентності майбутніх соціальних працівників у процесі підготовки до роботи з молодими сім'ями. Журнал Прикарпатського університету імені Василя Стефаника, 8 (1) (2021), 7-16. 
У статті актуалізовано проблему професійної підготовки майбутніх соціальних працівників щодо комплексу формування у них необхідних знань, умінь та навичок. Розглянуто погляди вчених щодо змісту понять компетентність, компетенції та професійна компетентність соціальних працівників. Також запропоновано авторські визначення поняття "компетентність", “компетенції, “професійна компетентність" та “соціально-правова компетентність". Актуалізовано проблему професійної підготовки майбутніх соціальних працівників щодо комплексу формування у них необхідних знань, умінь та навичок. Професійна компетентність є утворенням з різних компонентів, системою певних складових та особистісно-психодогічних властивостей особистості, що включає в себе знання, вміння, навики, особистісні характеристики та організаційно-педагогічні умови підготовки майбутніх спеціалістів. Визначено основні компоненти соціально-правової компетентності: когнітивний, діяльнісно-оперативний, мотивувальний, особистісний та інструментальний. Визначено види соціально-правових знань, які майбутні соціальні працівники отримують в процесі їх професійної підготовки та вміння і навички своєї професійної діяльності. Знання з соціально-правової діяльності для роботи 3 молодими сім'ями ми поділили на види за такими критеріями: соціальноправові знання за галузями права, соціально-правові знання одержані за ступенем їх ієрархії у законодавстві, соціально-правові знання за ступенем сформованості, соціально-правові знання за ступенем використання набутої інформації. Щодо набутих соціально-правових знань відповідно формуються вміння і навички соціально-правової діяльності, що становить діяльнісно-оперативний компонент соціально-правової компетентності: вміння і навички індивідуально-організаційної роботи, вміння і навички 3 прогнозовано-проектувальної роботи, вміння і навички 3 консуяьтативнозахисної роботи.

Запропоновано інструментальний компонент формування комплексних знань із соціальноправової діяльності, де виокремлюємо соціальне проєктування як сучасний прогресивний інструмент подолання соціальних проблем у роботі з молодими сім'ями. Розроблено соціальний проект під назвою “Освіта молодої сім'ї". Отож, без усіх компонентів соціально-правова діяльність не буде повною мірою здійснюватися та розвиватися соціально-правова компетентність. Безумовно, що усі компоненти є взаємопов'язаними та розвиваються разом, що свідчить про постійний особистісний саморозвиток та самовдосконалення соціальних працівників.

Кдючові слова: компетентність, компетенції, професійна компетентність, соціально-правова компетентність, компоненти соціально-правової компетентності, соціально-правові знання. 